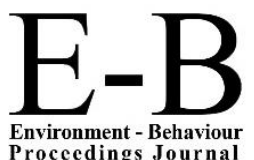

Environment - Behaviour
Procecdings Journal
AIVCE-BS-2, 2020ShahAlam

https://www.amerabra.org; https://fspu.uitm.edu.my/cebs; https://www.emasemasresources.com/ AMEABRA International Virtual Conference on Environment-Bahaviour Studies, $2^{\text {nd }}$ Series CE-Bs, FSPU, Universiti Teknologi MARA, Shah Alam, 02-03 Dec 2020

\section{e-IPH}

e-International Publishing House Ltd. United Kingdom

\title{
25 Years of Putrajaya Engineered Landscapes: Trend and perspectives
}

\author{
Jamalunlaili Abdullah¹, Raziah Ahmad², Muhammad Hafiz Zainal2 \\ ${ }^{1}$ Southeast Asia Built Environment Research Centre (SEABERC) / Centre of Studies for Town and Regional Planning, Faculty of \\ Architecture, Planning and Surveying, Universiti Teknologi MARA, Puncak Alam Campus, Malaysia \\ 2 Southeast Asia Built Environment Research Centre (SEABERC) / Centre of Studies for Landscape Architecture, Faculty of \\ Architecture, Planning and Surveying, Universiti Teknologi MARA, Puncak Alam Campus, Malaysia
}

jamal858@uitm.edu.my, razia841@uitm.edu.my, hafizzainal@uitm.edu.my

Tel. +60192627100

\begin{abstract}
2020 is the $25^{\text {th }}$ anniversary of Putrajaya, Malaysia's new Garden City administrative centre. But, the early development of this city has attracted critical views. This paper aims to examine Putrajaya's engineered landscapes' habitability and how they affect the quality of the living environment. The objective of this study is to identify the perceptions of professionals on these engineered landscapes and their contributions to users and the local community. It engages a descriptive analysis of webinar inputs by esteemed experts and professional respondents of an online survey. The results show that Putrajaya has potential as a planned green city model.
\end{abstract}

Keywords: Putrajaya; Garden City; landscape; administrative centre

eISSN: 2398-4287@ 2020. The Authors. Published for AMER ABRA CE-Bs by e-International Publishing House, Ltd., UK. This is an open access article under the CC BYNC-ND license (http://creativecommons.org/licenses/by-nc-nd/4.0). Peer-review under responsibility of AMER (Association of Malaysian Environment-Behaviour Researchers), ABRA (Association of Behavioural Researchers on Asians) and cE-Bs (Centre for Environment-Behaviour Studies), Faculty of Architecture, Planning \& Surveying, Universiti Teknologi MARA, Malaysia.

DOI: https://doi.org/10.21834/ebpj.v5i15.2361

\subsection{Introduction}

2020 is a significant year that marks the 25th year of Putrajaya, Malaysia's new administrative capital. These engineered landscapes have transformed 4,931-hectare of mostly oil palm plantations into one splendid planned city. Developed based on the theme "city in a garden" and "intelligent city," the early growth of this city has attracted critical views. This city was perceived as a series of ambitious projects, a "wilderness," a "white elephant project," and "forlornly desolate." (Moser, S. 2010). Instances of these observations were also found in Narayana, S. (2017), which highlighted how this new administrative centre brought negative impacts towards the original settlers' marginalization and the state of its habitability (Meng, L.L.et al., 2006).

Despite these criticisms, Putrajaya has drawn substantial researchers' interest in terms of its role as a new administrative centre (Ho, C.S. 2006; Tran. L.V. 2010; Kamarus Zaman et al. 2016), urban planning and design (Omar, D. 2004), garden city and placemaking (Devereux. M, 2015), urban parks and green spaces (Danjaji. A.S. et al. 2017), neighbourhoods and well-being (Ujang, N. et al. 2015; Ramli. R. et al. 2019). Nevertheless, there seems to be a lack of research that investigates the effectiveness of the engineered landscapes of this new town. Hence, this paper aims to investigate Putrajaya's engineered landscapes' habitability and how they affect the quality of living and working environment. The objective of this study is to identify the perceptions of professionals on these engineered landscapes and their contributions to users and the local community.

eISSN: 2398-4287C 2020. The Authors. Published for AMER ABRA cE-Bs by e-International Publishing House, Ltd., UK. This is an open access article under the CC BYNC-ND license (http://creativecommons.org/licenses/by-nc-nd/4.0/). Peer-review under responsibility of AMER (Association of Malaysian Environment-Behaviour Researchers), ABRA (Association of Behavioural Researchers on Asians) and cE-Bs (Centre for Environment-Behaviour Studies), Faculty of Architecture, Planning \& Surveying, Universiti Teknologi MARA, Malaysia.

DOI: https://doi.org/10.21834/ebpj.v5i15.2361. 


\subsection{Literature Review}

\subsection{Engineered Landscapes: People-Nature Value Orientation}

Teo, P. et al. (2004) discussed the concept of engineered landscape, which illuminates changes of landscapes in Singapore in the 1980s and 1990s impacted by rapid urbanisation and industrialization. Generally, researchers from a diverse field of studies perceived engineered landscapes as part of anthropogenic actions resulted from human activities and its natural environment in order to create more prosperous, safer, functional, contextual, and productive landscapes (Abdulrehman, S. 2015; Chase, A.F \& Chase, D. Z. 2016; El Amrousi, M. et al. 2019). In a similar vein, Fox et al. (2017) and Davies, P. \& Lawrence, S. (2019) connote engineered landscapes as a large-scale and long-lasting modification and transformation of natural resources in pursuit of cultural objectives that denote the durability of human innovations and inextricably linking urbanism and anthropogenic landscapes.

\subsection{Sustainability of Land Use Conversion}

Planning for new governmental administrative centres has begun since the late $19^{\text {th }}$ century. The phenomenon was found in Washington, D.C (1887) and Ottawa (1888), as well as other cities such as Canberra (1912), Chandigarh (1952), and Brasilia (1960). On 29th August 1995, these planned cities' footsteps were implemented in Putrajaya. Unfortunately, at a young age, the development of Putrajaya has received several critiques. One prominent earliest criticism came from Moser, S. (2010), who argued the conversion of greenfield land (agriculture) of Prang Besar (the original name of the site) was considered as unsustainable towards the "green" approach.

The conversion of greenfield agricultural land into mixed-land use has become a popular approach in the new urbanism. In Putrajaya's context, the oil palm plantation of Prang Besar was selected to become a new planned administrative centre for Malaysia. The decision to move the administrative centre from Kuala Lumpur to Putrajaya was based on a strategic location decision that plays an essential role in its land-use conversion (Asunmant 2018). In this context, Hooke, R.L et al. (2012) and Wu, J.J. (2018) pointed out that land-use change is necessary and essential for economic development and social progress. A series of recent studies have indicated the linkage between human activity and anthropogenic landscapes intensify in urban situations (Chase, A. F \& Chase. D.Z. 2016), where landscapes have been altered in various ways to fulfill the needs of daily life (Li-An, C. et al. 2018; Aziz, A \& Anwar. M.M. 2019).

\subsection{Social Mobility and Soul of City}

Cities are not designed and engineered like aeroplanes. Though every single city block, parks, roads, and neighbourhood are planned and designed, the city as a whole emerges as patterns of behaviour based on its evolution of the natural and built-environments. Many planned administrative cities such as Canberra and Brasilia have received criticism for their poor street design, which is unfriendly to pedestrians and dominates automotive footprint (Davies, A., 2013; Budds, D., 2019 \& Maddock, T., 2020). In this context, a similar phenomenon is also evident in Putrajaya. Research conducted by Borhan, N.M. et al. 2019) found the 'park and ride' service and public bus service operating in this city have failed in attracting commuters due to tardiness and long travel time.

The concept of the soul of the city was initially coined by Hueffer, F.M., (1905) that represents community, attachment, the feeling of safety, image, identity, and user's satisfaction (Kourtit, K. et al. 2020). Previous research showed that Putrajaya residents were satisfied with the environmental well-being of their neighbourhoods (Musa, H.D. et al., 2017). However, several authors (Norhisham, Q., et.al., 2013; Ngesan, M.R., \& Zubir, S.S., 2015) have highlighted the lack of Putrajaya city's soul due to the absence of retails and commercial activities. These findings in line with Ketchell, M., (2015) where the increase of pedestrian traffic and time spent outdoors walking, cycling, and sitting are seen as vital ingredients for the cohesive, healthy and vibrant community.

\subsection{Methodology}

\subsection{Study Area}

The study area is Putrajaya, Malaysia's third Federal Territory, which currently functions as Malaysia's administrative capital. The city is situated $25 \mathrm{~km}$ away from Kuala Lumpur and is nearly 5,000 hectares built on big marshland and oil palm estate. In 2019, Putrajaya's total population was estimated at 100,000, with an average annual population rate of 6.5 percent (Department of Statistics Malaysia, 2020).

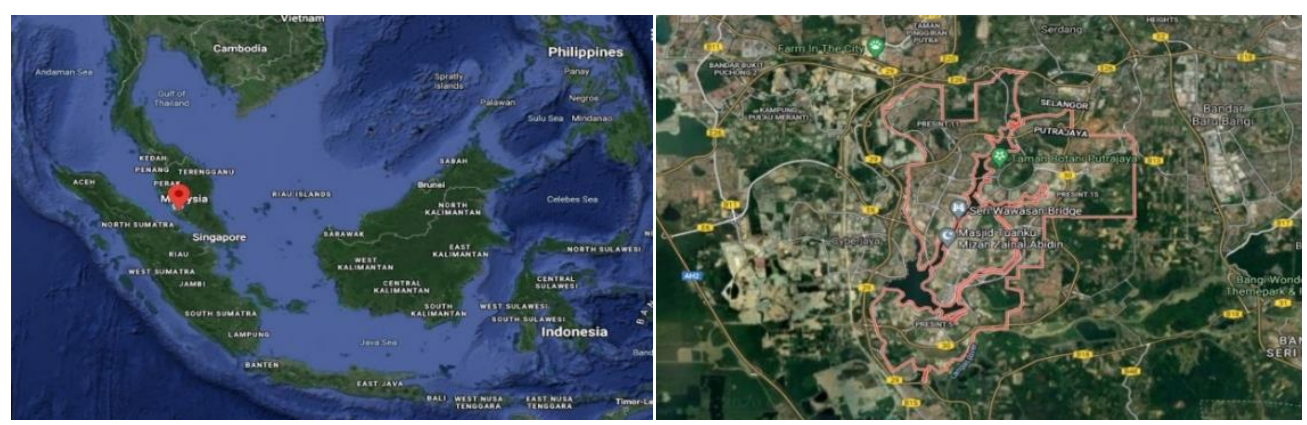

Figure 1.0: Key plan (left) and location plan (right) of Putrajaya, Malaysia. 


\subsection{Data collection}

This research uses secondary data, which were acquired from the Merdeka Special Webinar of critical consultants and designers of Putrajaya organized by Urbanice Malaysia, entitled "25th Anniversary of Putrajaya: Building on the Legacy" held on the $31^{\text {st }}$ August 2020 (Urbanice Webinar, 2020). Prominent speakers included Datuk Seri Jebasingam Issac John (CEO of Northern Corridor Implementation Authority), Tan Sri Dato' Sri Ar. Hj Esa Bin Hj Mohamed (Founder and Executive Chairman of Akitek Jururancang (Malaysia) Sdn Bhd), TPr. Norliza Hashim (CEO of Urbanice Malaysia), Kun Lim (Design Principal Kun Lim Studio LLC), Joe Sidek (Chairman of Federation of Asian Cultural Promotion, FACP) and was moderated by Ar. Mustapha Kamal of Pertubuhan Akitek Malaysia. Information from the panels' discussion was extracted and analysed (described in 4.0).

Furthermore, primary data were also collected from a survey questionnaire of built environment professionals using Google Form. The survey questionnaire was distributed to the officials ranging from grade 44 and above at the Jabatan Landskap Negara (JLN), Perbadanan Putrajaya (PPj), PLAN Malaysia, and others. A total of 35 respondents participated in the survey.

\subsection{Data Analysis}

There are two types of analyses conducted in this research. The first is the content analysis on the webinar held by Urbanice Malaysia, and the second is from the responses from the survey questionnaire conducted, which are descriptively analysed. Table 1.0 shows a summary of the analyses listed according to the attributes extracted from the webinar's virtual discussion. The survey questionnaire results provide insight into the most town planners' and landscape architects' responses on the knowledge and perception, satisfactory level, preference, and vision of Putrajaya's overall planning and design, especially regarding the engineered landscape elements. The data from both sources were comparatively analysed.

Out of 35 respondents of the survey questionnaire, 43\% are from PLAN Malaysia, $20 \%$ from JLN, $9 \%$ from PPj, and $29 \%$ are from the other agencies and organisations. All of the respondents are senior officials with J/G/N 48 (43\%) grade 44 (37\%), 52 (14\%), 54 (3\%), and JUSA C/B/A (3\%); who are involved in the policymaking related to the built environment. However, most of the respondents (89\%) do not live or stay in Putrajaya, and only $11 \%$ do reside there.

\subsection{Results and Discussion}

This section is divided into two parts. The first part summarizes an analysis of the "25th Anniversary of Putrajaya: Building on the Legacy" webinar. The second part focuses on the survey results of professionals in terms of knowledge and perception, satisfactory level on the landscape planning and design of Putrajaya, and future planning and design.

\subsection{5th Anniversary of Putrajaya: Building on the Legacy.}

Table 1.0 Summary analysis of the discussion from the 25th Anniversary of Putrajaya: Building on the Legacy webinar.

\begin{tabular}{|c|c|c|c|}
\hline No. & Attributes / issues & Descriptions & Suggestions \\
\hline \multicolumn{4}{|c|}{ A. Accomplishments to be proud of } \\
\hline 1 & $\begin{array}{l}\text { Sustainability and } \\
\text { Putrajaya as a green } \\
\text { city. }\end{array}$ & \multicolumn{2}{|c|}{$\begin{array}{l}\text { - Sustainable low carbon footprint embedded in the structural plan; } \\
\text { - Very committed to sustainability. } 40+\% \text { of the city are green and blue. No city in Malaysia } \\
\text { has the amount of greenery; } \\
\text { - The amount of biodiversity (wetlands) achieved in short time of } 25 \text { years is astounding; } \\
\text { - Some principles on the water body have been set, thus not everything could be undone } \\
\text { without valid reason. }\end{array}$} \\
\hline 2 & Image and Identity & \multicolumn{2}{|c|}{$\begin{array}{ll}\text { - } & \text { Planned, designed and built by Malaysians } \\
\text { - } & \text { International icon and reference (particularly among the Islamic States) }\end{array}$} \\
\hline \multicolumn{4}{|c|}{ B. Areas of concern } \\
\hline 1 & $\begin{array}{l}\text { Shortfall of planning, } \\
\text { design and } \\
\text { development. }\end{array}$ & $\begin{array}{l}\text { - The city is too clinical } \\
\text { and it lacks soul; } \\
\text { - Undeveloped } 4 \text { million } \\
\text { sq./ft. of designated } \\
\text { commercial space; } \\
\text { - }{ }^{2} \text { attractions to keep } \\
\text { the tourists to stay long; } \\
\text { Disconnected public } \\
\text { transportation system. }\end{array}$ & $\begin{array}{l}\text { - } \quad \text { Inject infill development } \\
\text { - } \quad \text { Putrajaya to create more vibrancy; } \\
\text { - } \quad \text { walk comfortably from one area to another; } \\
\text { - } \quad \text { Build the tram / railway system as initially planned; }\end{array}$ \\
\hline
\end{tabular}




\begin{tabular}{|c|c|c|c|}
\hline 2 & Inclusivity & $\begin{array}{l}\text { - Governmental precincts } \\
\text { worldwide are dead city } \\
\text { - to avoid Putrajaya } \\
\text { from becoming one; } \\
\text { - No visible industry; } \\
\text { - The Malay reserve is } \\
\text { huge and not being } \\
\text { inclusive; } \\
\text { Only one university in } \\
\text { Putrajaya; }\end{array}$ & $\begin{array}{l}\text { - } \quad \text { Digitalization, artificial intelligence, big data will } \\
\text { encourage private sectors to come to establish } \\
\text { manufacturing activities and businesses, instead of } \\
\text { only administrative agencies; } \\
\text { - } \quad \text { Need to be inclusive, with other aspects need to be } \\
\text { brought in, leveraging on development in Cyberjaya; } \\
\text { - } \quad \text { Agricultural activities using high technology; } \\
\text { - } \quad \text { Education hub; } \\
\text { - } \quad \text { Medical and health tourism; } \\
\text { - } 24 \text { hours' activities in the mixed development area. }\end{array}$ \\
\hline 3 & $\begin{array}{l}\text { Tourist, visitors vs. } \\
\text { local community }\end{array}$ & $\begin{array}{l}\text { - Visitors think that Putrajay } \\
\text { place, and adding more } p \\
\text { - } \quad \text { For the local community, i } \\
\text { - Thus, the quality of life } \\
\text { compromised. }\end{array}$ & $\begin{array}{l}\text { more liveability to be enjoyed by those who are visiting the } \\
\text { the core areas to live in; } \\
\text { eable city with a good quality of life; } \\
\text { ople who are already enjoying it there should not be }\end{array}$ \\
\hline \multicolumn{4}{|c|}{ C. The way forward } \\
\hline 1 & $\begin{array}{l}\text { Things need to } \\
\text { happen in Putrajaya } \\
\text { in the future }\end{array}$ & \multicolumn{2}{|c|}{$\begin{array}{l}\text { - } \quad \text { Attractive, people friendly, environmentally sustainable, and embody digital technology; } \\
\text { - } \quad \text { Diversity, inclusive, progressive and vibrant; } \\
\text { - } \quad \text { Creating excellence that people may continue learn from. } \\
\text { - } \quad \text { City with a soul } \\
\text { - } \quad \text { Model of green city and inspire other cities }\end{array}$} \\
\hline
\end{tabular}

(Source: Authors' Analysis of virtual webinar, 2020 (https:/www.facebook.com/watch/live/?v=628898774490391\&ref=watch_permalink)

Besides being cited as a good benchmark by other countries (Bernama, 2020), the five panelists focused on three main aspects. First, while they concurred the physical infrastructure such as public transportation and commercials were incorporated in the early blueprint, integrated public transport, often seen as a social service, is still a distant dream. Likewise, the coarse grains, coupled with the lack of commercial and retail activities along the main boulevard of Putrajaya, contribute to less vibrancy and city souls' absence. This is also the findings by Moser, S. (2010 and Norhisham, Q. et al. (2013). Hence, the panels argue that infill development that welcomes diverse building use and improving integrated and efficient public transport would overcome this young city's current flaws.

Second, to attract business activities and private investors, the panellists urged this city to be more inclusive in commercial, retail, and technology digitalisation. Putrajaya liveliness and good quality of life is the third thematic point made by the panellists. Though they agreed with the residents' enjoyment of the public facilities and amenities within their neighbourhood, the city should be injecting more activities that would attract visitors and tourists to stay longer. According to Nair, V. (2019), the virtuous living blueprint created for a productive environment to live, work and play events, namely Putrajaya Oxygenation Dragon Boat Race 2019, Putrajaya Bird Race 2019, and Putrajaya Wind Orchestra competition hosted by the Putrajaya Corporation (PjC) certainly can enliven this young administrative capital.

Despite criticisms received in the early development of Putrajaya (Moser, S. 2010; Narayanan, S. 2017), the panelilsts were being optimistic about its outstanding achievements so far. First, green sustainable development has been considered in the Putrajaya Master Plan, where almost $40 \%$ of the city area is designated as open space. This includes 400 acres of man-made lakes and 200 hectares of wetland, created to bring nature and biodiversity into the city fabric. Second, this new planned administrative centre has magnificently built its image and identity, which is aesthetically pleasing and inspired other Muslim countries. Another good observation is that to transform this city into a sustainable city model, Putrajaya should enhance its vibrancy, habitability, and connectivity.

\subsection{Knowledge and Perception}

In terms of the engineered landscape knowledge, $46 \%$ of the respondents answered that they have moderate knowledge. Meanwhile, $29 \%$ are quite knowledgeable on the subject, $23 \%$ are experts on it, and only $3 \%$ have a little knowledge of the topic, which means $97 \%$ of the respondents can be considered knowledgeable. The majority (54\%) of the respondents perceived engineered landscape as a replacement for single land use (oil palm plantation) in Putrajaya as very efficient. $29 \%$ of the respondents even recognized it as extremely efficient, while the other $54 \%$ feel it is moderately efficient, and none consider it as not efficient at all. Subsequently, the observation made by Ho. C.S (2006) supports the respondent's perception of the land-use conversion, where Putrajaya's planning and design provide a useful benchmark that incorporates ecology, cultural heritage, community, and neighbourhood concept as well as art and technology.

In terms of the implications of converting the single land use into an engineered landscape, all of the respondents perceived the changes positively affected the economy, social and environmental aspects of this city, where $37 \%$ of them consider the effects as excellent. In comparison, another $34 \%$ and $29 \%$, respectively, suggested they are excellent and moderately good. A prominent example reflecting this survey result is the Heriot-Watt University's Malaysia Campus buildings that can serve as a built green campus model that combines nature and technology (Heriot-Watt University, 2013; Dublin, D.B. et al. 2014).

As the policymakers, the respondents deliberate Utopian Garden City as a concept that portrays Putrajaya's image as a success. To support that result, the majority (46\%) of the respondents noticed that the natural capitals such as green spaces and water bodies 
had been considered in the early planning and development of Putrajaya's landscape. The present study confirmed the remark made by Douglas, I. (2019). The emphasis on environmental conservation and equitable access to open green spaces become primary elements of designing with nature. Some westerners have criticized Putrajaya's engineered landscape as an ambitious planned city, a wilderness, and a white elephant project (Moser, S. 2010). Conversely, $46 \%$ of the policymakers strongly disagreed, and $23 \%$ disagreed with those skeptical views. Only $17 \%$ moderately agreed, and $14 \%$ agreed with those opinions.

\subsection{Satisfactory Level on the Landscape Planning and Design of Putrajaya}

The satisfactory level of landscape planning and design can be considered acceptable, as all five of the attributes shown in Figure 2.0 received overall satisfactory feedback. Similar findings were reached by Omar, D. (2006) and Musa, H.D. et al. (2018) that revealed that community happiness depends on a good performance of eco-environmental well-being and human well-being.

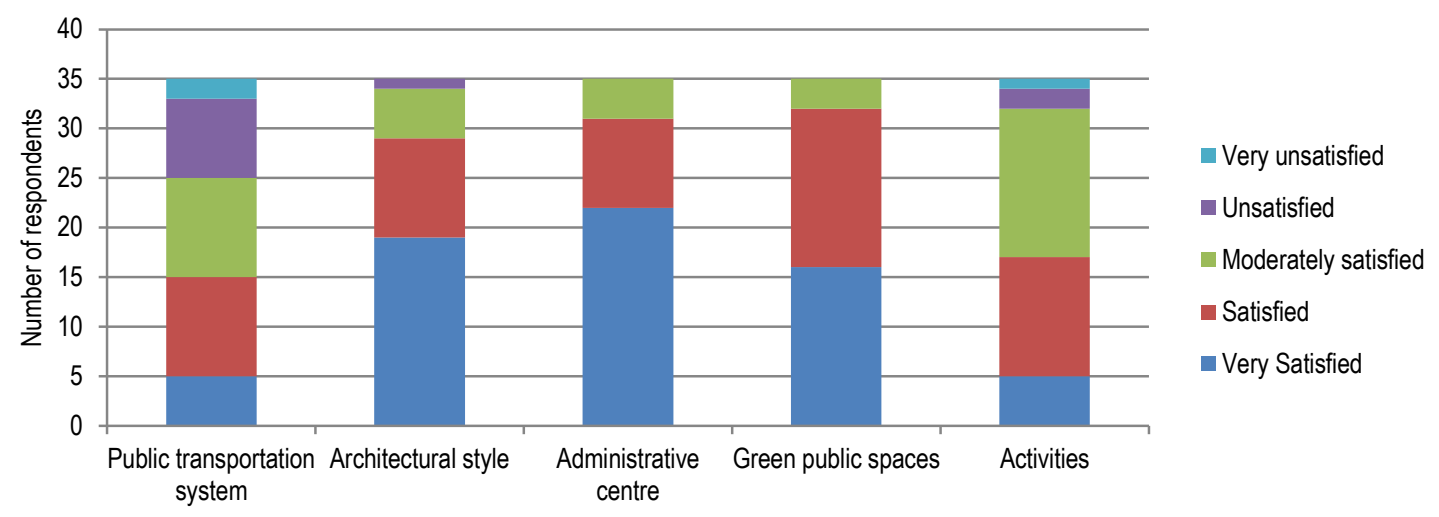

Figure 2.0 Summary on the Satisfaction Level on the Landscape Planning and Design of Putrajaya.

Of the five attributes, $91 \%$ of the respondents agreed that the public transportation system requires the most immediate rectifying action, followed by $83 \%$ activities. This result is consistent with what has been found in Borhan, N.M et al. (2019), which stated that a more reliable and accessible public transport service needs to be improved, while Khan, R. (2018) Mohd. T, F. \& Rosly, DD. ( 2020) conveyed their apprehension over the lack of safe, efficient, and integrated public transport, which to date failed to be implemented. The policymakers also feel that Putrajaya is indeed a safe city, as a whopping $97 \%$ of the respondents agreed. Another reference that broadly supports this finding is NUMBEO (2020), where the crime index of Putrajaya is considered low (20.04) while the safety index is 79.96. The critical point associated with the high safety and security level in the fenceless neighbourhood of Putrajaya is the partnership between residents and police (Fernandez, C. 2010; Chen, G. 2018)

Putrajaya has established 11 main public parks in which $51 \%$ of the respondents agreed to manage to play their roles efficiently for the community. This result ties nicely with previous studies wherein the ecological design and aesthetic enhancement are incorporated in the urban green spaces of Putrajaya (Ibrahim, R. 2016; Talib, N. 2017; Danjaji, A.S. et al. (2018). Besides, most of the respondents $(57 \%)$ also feel that Universal Design has been much considered and implemented in Putrajaya's planning and design. A similar pattern of results that supports this observation was found in Abdul Kadir, S. \& Jamaluddin, M. (2012); Abdullah, R.J. (2013); Nair, V. (2019). In terms of the thermal comfort in Putrajaya, the respondents think that it is only moderately comfortable. Together, the present finding endorsed the research outputs conducted by Salleh, S. A. et al. (2013) and Morris, K. et al. 2016). The urban heat island phenomenon in Putrajaya is affected by urbanisation and climate change. Overall, the quality of the living environment in Putrajaya can be considered as good. Figure 3.0 below demonstrates the statistic on the satisfactory level of the explained qualities.

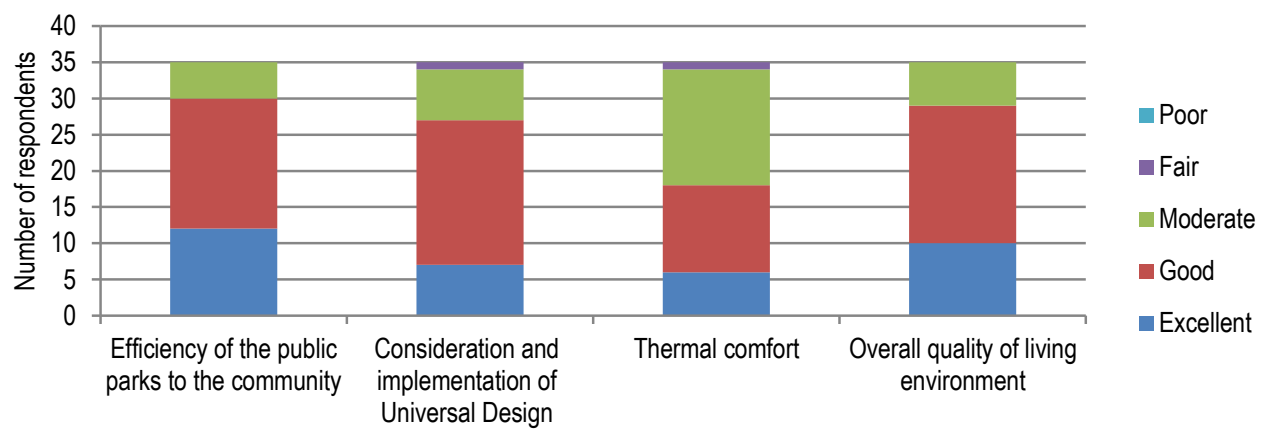

Figure 3.0 Summary on the Satisfaction Level on the Selected Qualities of Living in Putrajaya. 


\subsection{Future Planning and Design}

For Putrajaya's future planning and design, the respondents were asked how they visualize Putrajaya in the next 25 years based on several attributes, as summarized in Figure $4.0 .80 \%$ of the respondents agreed that the dependency on Putrajaya's motorized vehicle should be reduced. Hence, it suggests that Putrajaya's cityscapes designed with cars in mind should be transformed into eco-friendly pedestrian linkage, where walkability should be encouraged and promoted (Azmi, D.I \& Ahmad, P. 2014; Khan, R. 2018). Another promising finding is that $70 \%$ of the respondents are keen to have more retails and commercial within the government complexes. The result provides evidence to the previous study conducted by Ngesan, M.R \& Zubir, S. S. (2015), where urban public parks are often used for nighttime leisure activities.

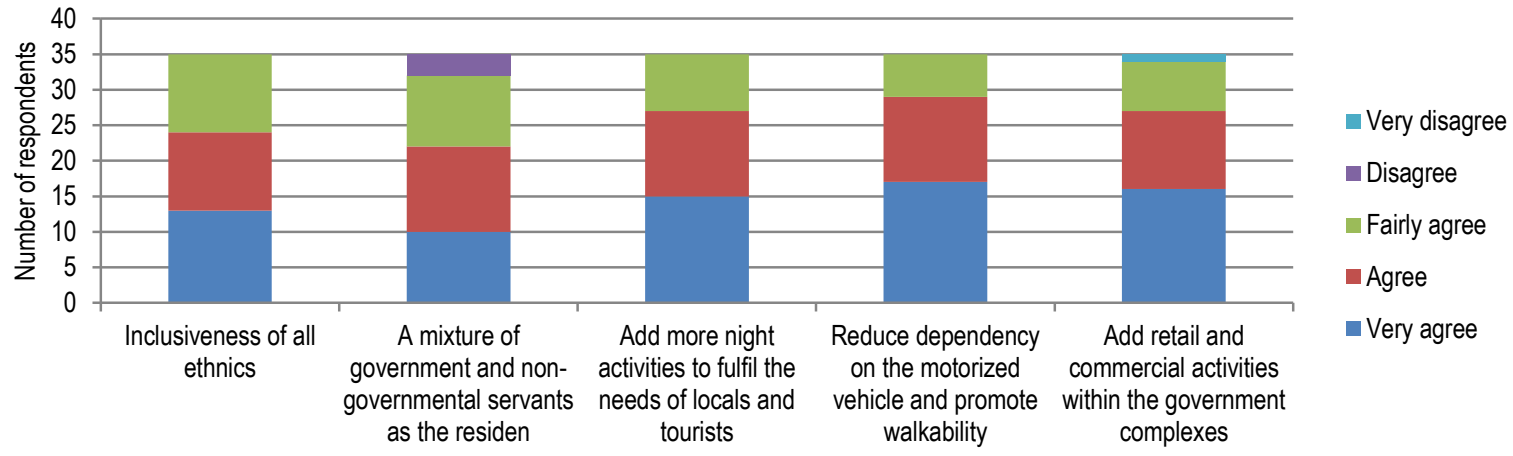

Figure 4.0 Summary of the Perception for the Future Planning and Design of Putrajaya

On average, $70 \%$ of the respondents embraced the inclusion of a multi-racial society residing or working in Putrajaya. The result cast a new light on Moser's opinion (2010) on how Putrajaya has paved a new direction for contemporary Malaysian cultural and racial politics for Southeast Asian Urbanism. The majority (94\%) of the respondents think Putrajaya can become a green city model for other cities in Malaysia. This finding is by the Putrajaya Structure Plan 2025 that further reinforces and supports the transformation of Putrajaya from a city in a garden into a green city (Ho, C.S. et al. (2011); Perbadanan Putrajaya, 2013).

\subsection{Core Findings}

The core findings of the study are summarized below. The following are its positive attributes:

- Generally, Putrajaya has achieved its primary objective to be a garden city with excellent green spaces where almost $40 \%$ of the city area is designated as open space.

- The new planned administrative centre has admirably built its image and identity, which is aesthetically pleasing and inspired other Muslim countries.

- Excellent administrative centre, architecturally significant buildings, and green public spaces are Putrajaya's primary attributes

- contributing to its residents' quality of life environment.

While there are many positive attributes, the following are some of the shortcomings of Putrajaya

- It lacks soul due to the central government district being empty after office hours due to lack of activities

- The public transportation system is very inefficient despite its being part of the masterplan.

\subsection{Limitations of Study}

This study has been steered based on in-depth comments of esteemed panels during a webinar session and a survey of professionals who are mainly town planners and landscape architects. The study's limitation is perhaps the lack of analysis among Putrajaya residents who know their neighbourhood intimately. The professionals who participated are mostly town planners and landscape architects, which is not very inclusive. Further, due to limited time, aspects of habitability of buildings, residential, image, and identity of Putrajaya were excluded from the research. Perhaps these can be addressed in subsequent research.

\subsection{Conclusion and Recommendation}

This research has provided a snapshot of Putrajaya's state of habitability and shortcomings after 25 years of existence. While the achievements are commendable, this research paper proposes some measures to address the panels and respondents' issues primarily related to the lack of the city's soul and the transportation issue. It was stated that a rail-based transportation system was originally envisioned in the masterplan. As a matter of fact, the right of way had been designated, and tunnels were dug for this purpose. Perhaps when the number of residents achieved the targeted threshold and the government budget permits, rail-based public transportation will eventually be built within the city. In the meantime, a more efficient bus transport system should be implemented comprehensively. 
To address the issue of lack of soul of the city, it is proposed that a mixed development be intensified in the government precincts whereby residences are built close to or next to government buildings. This approach will provide the population who will throng the areas after office hours and support the commercial activities' precinct. Residents of various ethnic groups, not just Malays, would provide more inclusivity to the area and support diverse city activities. These recommendations have been proposed by the panels and respondents as well. Future research should further investigate the extent to which the rail-based transportation system and the infill development for retails and commercials have been considered and implemented in Putrajaya future planning.

\section{Acknowledgements}

The authors would like to express special gratitude and thanks to all built environment professionals from the Jabatan Landskap Negara (JLN), Perbadanan Putrajaya (PPj), PLAN Malaysia and other agencies whose co-operation has contributed a significant part of this research. We are also thankful to the anonymous reviewers for their valuable comments and suggestions.

\section{Paper contribution to the related field of study}

As landscape urbanism that supports the notion of the engineered landscapes is relatively a new concept in the practice of landscape architecture in Malaysia, findings of this study would provide insight into how the city is constructed of nexus of physical-social-ecological rich horizontal settings, rather than just planning and designing of objects and buildings. Moreover, finding also demonstrates that transforming the greenfield into habitable urban landscapes has proven beneficial to creating the city's image and quality of life of the local community, reflecting the clear vision of Putrajaya as a new Garden City administrative centre.

\section{References}

Abdul Kadir, S., \& Jamaludin, M. (2012). Applicability of Malaysian standards and universal design in public buildings in Putrajaya. Asian Journal of Environment-Behaviour Studies. 3(9).

Abdullah, R.J. (2013). Application of universal design in public buildings in Putrajaya. Master's Dissertation, Universiti Teknologi Malaysia, Skudai, Johor. Retrieved from http://eprints.utm.my/id/eprint/41788/5/RebazJalilAbdullahMFAB2013.pdf

Abdulrehman, S. (2015). Engineered landscapes: Re-thinking sacrificed landscapes in the Canadian prairies. Master's Dissertation, University of Manitoba,, Winnipeg, Canada. Retrieved from https://www.bac-lac.gc.ca/eng/services/theses/Pages/item.aspx?idNumber=1032992876

Almas, P., \& Nursalikah, Ani. (2019). Relocation of Indonesia's capital different from Malaysia. Retrieved from https://www.republika.co.id/berita/nasional/daerah/pwxs7n463/en/national-politics/19/08/27/pww6ja366-relocation-of-indonesias-capital-different-from-malaysia.

Amrousi, M. E., Elhakim, M., Paleologos, E. \& Misuri, A. (2019). Engineered landscapes: The new Dubai canal and emerging public spaces. International Review for Spatial Planning and Sustainable Development. 7(3), 33-44. doi: http://dx.doi.org/10.14246/irspsd.7.3_33.

Ansumant, (2018). Greenfield development. Retrieved from https://planningtank.com/urbanisation/greenfield-development.

Aziz, A. \& Anwar, M. M. (2019). Landscape change and human environment. Environment, Earth and Ecology. 3(1),7-12. doi: 10.24051/eee/110396.

Azmi, D. I., Abdul Karim, H., \& Ahmad, P. (2013). Comparative study of neighbourhood walkability to community facilities between two precincts in Putrajaya. Procedia Social and Behavioral Sciences. 105, 513-524.

Bernama. (2020). Putrajaya urged to be inclusive in consultations on digitalisation in financial sector.

Borhan, M. N., Ibrahim, A.N.H., Syamsunur, D., \& Rahmat, R.A. (2019). Why public bus is a less attractive mode of transport: A case study of Putrajaya, Malaysia. Periodica Polytechnica Transportation Engineering. 47(1), 82-90, https://doi.org/10.3311/PPtr.9228

Chase, A. F., \& Chase, D. Z. (2016). Urbanism and anthropogenic landscapes. Annu. Rev. Anthropol. 45(22),1-22.

Chen. G. (2018). Steps taken to tighten security in Putrajaya. Retrieved from https://www.thestar.com.my/metro/metro-news/2018/11/26/steps-taken-to-tighten---securityin-putrajaya.

Danjaji, A. S., Ariffin, M., Sharaai, A. H. \& Yunos, Y. M. (2017). Impact of urban green space attribute on visitors' satisfaction in Putrajaya, Malaysia. Int. J. Environment and Sustainable Development, 17(1).

Davies, P., \& Lawrence, S. (2019). Engineered landscapes of the southern Murray-Darling Basin: Anthropocene archaeology in Australia. The Anthropocene Review 2019. 6(3), 179-206. doi: $10.1177 / 2053019619872826$

Department of Statistics Malaysia (2020). Retrieved from https://www.dosm.gov.my/v1/index.php?r=column/cone\&menu_id=bkJnUlk2WXUyTOhVWm5IZXlubERjUT09.

Devereux, M. (2015). International interpretations of the garden city ideal: Lessons for placemaking. Urban Design -New Series-, 134, 32-34. Retrieved from https://uwerepository.worktribe.com/output/834674/international-interpretations-of-the-garden-city-ideal-lessons-for-placemaking

Dublin, D., R., Crucio, E.P., Phillips, R., Singh, S. \& Lertsahakal, J. (2014). Sustainable development in Kuala Lumpur and Putrajaya: A case study of leadership initiatives within the education sector. Retrieved from https://prospernet.ias.unu.edu/activities/p/2014/p/sustainable-development-in-kuala-lumpur-and-putrajaya. 
Fernandez, C. (2010). Putrajaya a safe city to live in. Retrieved from https://www.thestar.com.my/news/community/2010/09/17/putrajaya-a-safe-city-to-livein\#: :text=THE\%20crime\%20index\%20in\%20Putrajaya,to\%20keep\%20crime\%20at\%20bay.

Fox, T., Pope, M., \& Ellis, E. C. (2017). Engineering the anthropocene: Scalable social networks and resilience building in human evolutionary timescales. The Anthropocene Review. 4(3),199-215.

Heriot-Watt University, (2013). Heriot-Watt University is Malaysia's first purpose-built green campus. Retrieved from https://www.hw.ac.uk/news/articles/2013/heriot-wattuniversity-is-malaysia-s-first.htm.

Ho, C. S. (2006). Putrajaya - administrative centre of Malaysia: Planning concept and implementation. Sustainable Urban Development and Governance Conference SungKyunKwan University, Seoul.

Ho. C. S., Matsuoka, Y. \& Hashim, O. (2011). Putrajaya green city 2025. Baseline and preliminary study. Retrieved from http://2050.nies.go.jp/report/file/lcs_asialocal/Putrajaya_2011.pdf.

Hooke, R. L., Martín-Duque, J. F., \& Pedraza, J. (2012). Land transformation by humans: A review. GSA Today. 22(12). doi: 10.1130/GSAT151A.1.

Hueffer, F.M. (1905). The Soul of London. Charles Wittingham, London.

Ibrahim, R. (2016). Towards a sustainable landscape of urban parks in Kuala Lumpur, Malaysia: A study from a management perspective.

Kamarus Zaman, N. A., Ahmad, H., Er, A. C., Kamarus Zaman, N.A. \& Jusoh, H. (2016). Pusat pentadbiran Putrajaya sebagai destinasi pelancongan: Satu analisis SWOT produk pelancongan. Journal of Society and Space. 12(13), 74-88.

Kaur, D. (2019). The journey of Putrajaya - Malaysia's jewel capital city. Retrieved from https://themalaysianreserve.com/2019/01/31/the-journey-of-putrajaya-malaysiasjewel-capital-cityl.

Ketchell, M., (2015). How do we create liveable cities? First, we must work out the key ingredients. Retrieved from https://theconversation.com/how-do-we-create-liveablecities-first-we-must-work-out-the-key-ingredients-50898

Kourtit, K., Nijkamp, P., \& Wahlström, M. H. (2020). Land Use Policy. Retrieved from https://doi.org/10.1016/j.landusepol.2020.104734

Li-An, C., Billa, L., \& Azari, M. (2018). Anthropocene climate and landscape change that increases flood disasters. Int J Hydro. 2(4),487-491.

Maddocks, T. (2020). Can Canberra, a city built for the car, be retrofitted so its commuters prefer public transport? Retrieved from https://www.abc.net.au/news/2020-08$16 /$ canberra-is-built-for-cars-how-can-public-transport-network-fit/12556220?nw=0

Meng, L. L., Abdullah, A., Fern, T. S., Badarulzaman, N. \& Hassan, A. S. (2006). How we failed to plan for habitability. Planning Malaysia Journal of the Malaysian Institute of Planners. 4, 1-21.

Mohd Taib, F., \& Rosly, D. (2020). Good public transport still a distant dream. Retrieved from https://www.nst.com.my/news/nation/2020/01/555246/good-public-transportstill-distant-dream.

Morris, K I., Chan, A., Ooi, M.C., Oozeer, M.Y., Abakr, Y.A. \& Morris, K.J.K. (2016). Effect of vegetation and waterbody on the garden city concept: An evaluation study using a newly developed city, Putrajaya, Malaysia. Computers, Environment and Urban Systems. 58 (2016), 39-51. https://doi.org/10.1016/j.compenvurbsys.2016.03.005 Moser, S. (2010). Putrajaya: Malaysia's new federal administrative capital cities. Cities. 27(4), 285-297.

Musa, H. D., Yacob, M. R., Abdullah, A.M., \& Ishak, M.Y. (2017). Sustainable City: Assessing the Community Happiness of Residents in Putrajaya Municipality Malaysia.Review of European Studies; Vol. 9, No. 1.

Nair. V. (2019). Transportation issues in Putrajaya. Retrieved from https://www.thestar.com.my/metro/metro-news/2019/10/11/transportation-issues-in-putrajaya.

Nayaranan, S. (2017). Putrajaya new town development, force displacement and resettlement: The social impacts on the original settlers. Journal of Education and Social Sciences. 7(1).

Ngesan, M. R., \& Zubir, S. S. (2015). Place identity of nighttime urban public park in Shah Alam and Putrajaya. AcE-Bs2014Seoul Asian Conference on EnvironmentBehaviour Studies. 170, 452 - 462.

Norhisham, Q., Rahman, Y., \& Zubir, S. S. (2013). Unveiling the potentialities of urban space in Putrajaya. WIT Transactions on Ecology and The Environment. 179. doi:10.2495/SC130051.

NUMBEO. (2020). Crime in Putrajaya, Malaysia. Retrieved from https://www.numbeo.com/crime/in/Putrajaya-Malaysia.

Omar, D. (2004). The total planning doctrine and Putrajaya development. The Sustainable City III. N. Marchettini, C. A. Brebbia, E. Tiezzi \& L. C. Wadhwa (Editors), WIT Press

Ramli, R., Omar, D., \& Ahmad, P. (2019). Malaysia's green neighbourhood initiatives: Implementing and approach in Putrajaya, Selangor and Johor. International Journal of Engineering and Advanced Technology (IJEAT). 8(5C).

Teo, P., Yeoh, B., Ooi, G.L. \& Lai, K. (2004). Changing landscapes of Singapore. McGraw Hill, Asia.

Ujang, N., Moulay, A., \& Zakariya, K. (2015). Sense of well-being indicators: Attachment to public parks in Putrajaya, Malaysia. Social and Behavioral Sciences. 202, 487-494.

Wu, J. J. (2008). Land use changes: Economic, social, and environmental impacts. Choices 4th Quarter. 23(4). 